\title{
Hedonic Value and Utilitarian Value on Product Purchasing Decision in Food Truck Business
}

\author{
Tona Aurora Lubis
}

\author{
Universitas Jambi, Indonesia \\ *Corresponding author. Email: tonalubis@unja.ac.id
}

\begin{abstract}
The emergence of Food and Beverages way selling by using food truck business facility. Citizens responded to it with high enthusiasm. The purpose of this study is to analyze the influence of Hedonic and Utilitarian values on product purchasing decisions in the Food Truck business. This type of research is mixed-method research with a Sequential Exploratory Design Research Type. This type used 2 (two) stages, the first stage using qualitative and then continued by using quantitative. The respondents used in this research are the customers who have made transactions with the Food Truck business, in Jambi City. This study concludes that the influence of hedonic value is more dominant than the utilitarian value on product purchasing decision in the Food Truck business
\end{abstract}

Keywords: Department of Economic and Business, Jambi University.

\section{INTRODUCTION}

According to the Indonesian Ministry of Industry (Kemenperin), the food and beverage sector succeeded in contributing $6.43 \%$ of the National Gross Domestic Product (GDP) in 2018. This figure is projected to continue to grow and develop in line with the government's focus on the creative industry sector, one of the subsectors is culinary.

The culinary industry grows and develops due to the phenomenon of growth and development of the street food business. One of these developments is the way of selling via trucks or "mobile restaurants" which is better known as the Food Truck.

In the United States the Food Truck business has grown over the last five years (Annenberg and Kung, [1]. The Food Truck industry has reached a value of 856.7 million dollars in 2015 and will increase to 996.2 million dollars in 2020 (Statistics Database) [2]. Meanwhile, the Food Truck business began to enter Indonesia in 2013. The Food Truck business continues to grow and develop from year to year. The Food Truck business continues to grow and already has a forum, namely the Indonesian Food Truck Association (AFTI). Likewise, the Food Truck business in Jambi City continues to grow and develop with various types of food and beverages on offer.
Business behavior from a consumer's point of view results in an assessment of consumer behavior. Batra and Ahtola [3], Arnold and Reynolds [4], and Lim and Ang [5] concluded that in general, a person has consumption behavior based on two things: (a) entertainment and emotional values (hedonic), and (b) instrumental and rational (utilitarian) values. Research by Bridges and Florsheim, [6] confirms that hedonic and utilitarian values are important considerations in understanding consumer behavior. Ryu, Han, Jang [7] state that hedonic and utilitarian values represent an evaluation of the overall motive for consumption behavior. Overby and Lee [8] explain that hedonic value refers to the overall assessment of the experience of benefits and sacrifices received, such as joy and pleasure, while utilitarian values consider the overall assessment of functional benefits and sacrifices, such as economic value and timesaving valuations.

Babin, Darden, and Griffin [9] explain that hedonic value reflects the emotional and affective aspects of consumer behavior, such as joy and pleasure. More specifically, hedonic values are more personal and subjective values generated by pleasure and pleasure, not by minimum costs.

In contrast, Babin et al [9] also explained that utilitarian values reflect rational and task-oriented aspects of the economy, which are traditionally instrumental, cognitive, and functional. On the other 
hand Kim, Sun, Kim [10] assert that utilitarian values are traditionally considered to be the main drivers of consumer choice.

This research is interesting because of the phenomenon of growth and development of the food truck business in the city of Jambi. On the other hand, this research is important because there is a research gap in a form of the absence of food truck research in a view of management and business science in Jambi City. Therefore, the purpose of this study is to analyze the effect of hedonic value and utilitarian value on purchasing decisions.

\section{METHOD}

This type of research is mixed-method research with a Sequential Exploratory Design Research Type. This type used 2 (two) stages, the first stage using qualitative and then continued by using quantitative. At the qualitative stage using respondents who have made transactions with the food truck business, in Jambi City. The number of respondents as informants was 20 people. This information is processed with NVIVO 11 Pro software. At the qualitative stage, themes and sub-themes are obtained. In the quantitative stage, the total sample was 160 people. Data from respondents were processed using PLS 2.3 software. At this stage, the influence between variables is obtained.

\section{RESULT}

After going through qualitative research steps, the following output results are obtained:
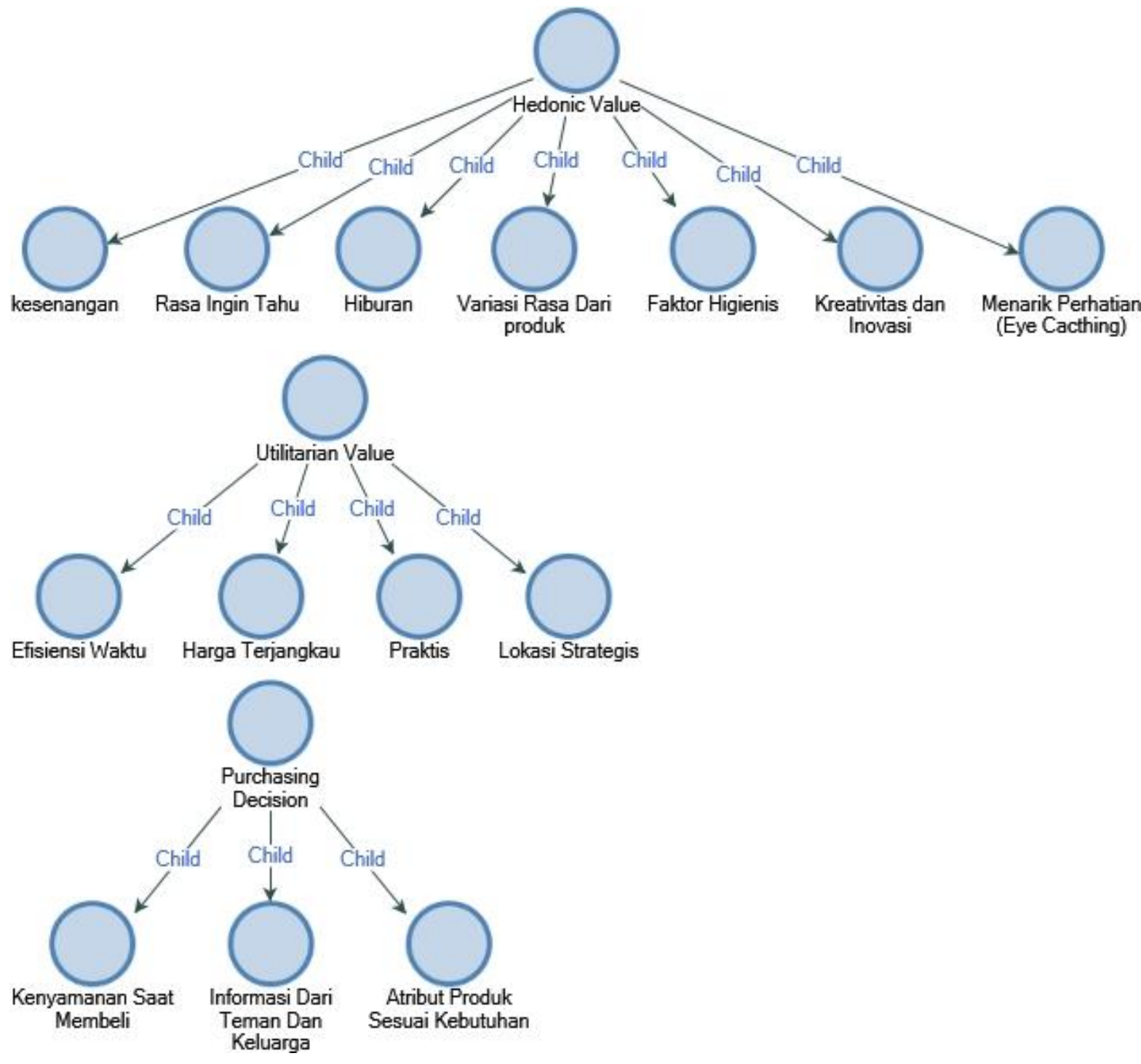

Source: NVIVO Output

Figure 1: Project Map Purchasing Decision, Hedonic Value, and Utilitarian Value 


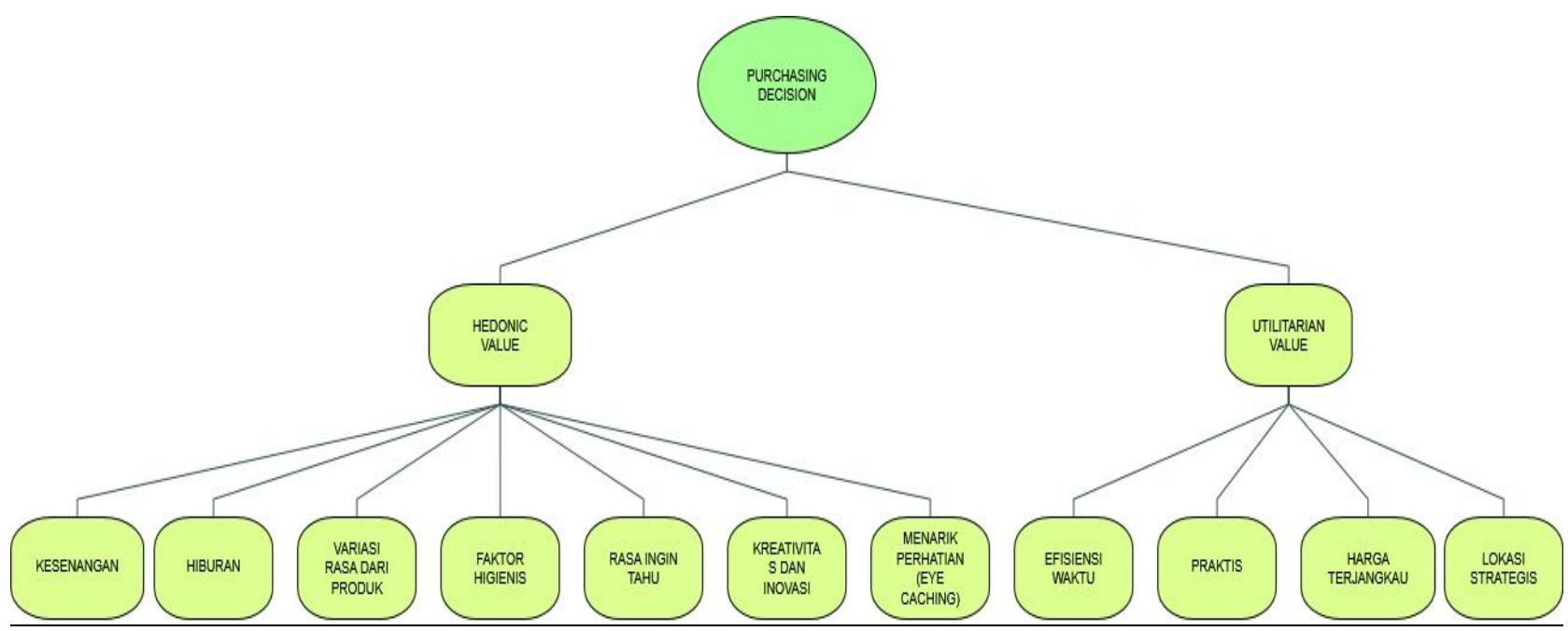

Source: NVIVO Output

Figure 2: Mind Mapping Purchasing Decision, Hedonic Value, and Utilitarian Value

The results of the qualitative stage output in the form of themes and sub-themes will then be used as variables and indicators at the quantitative stage. The results of the Iquantitative stage output are as follows:

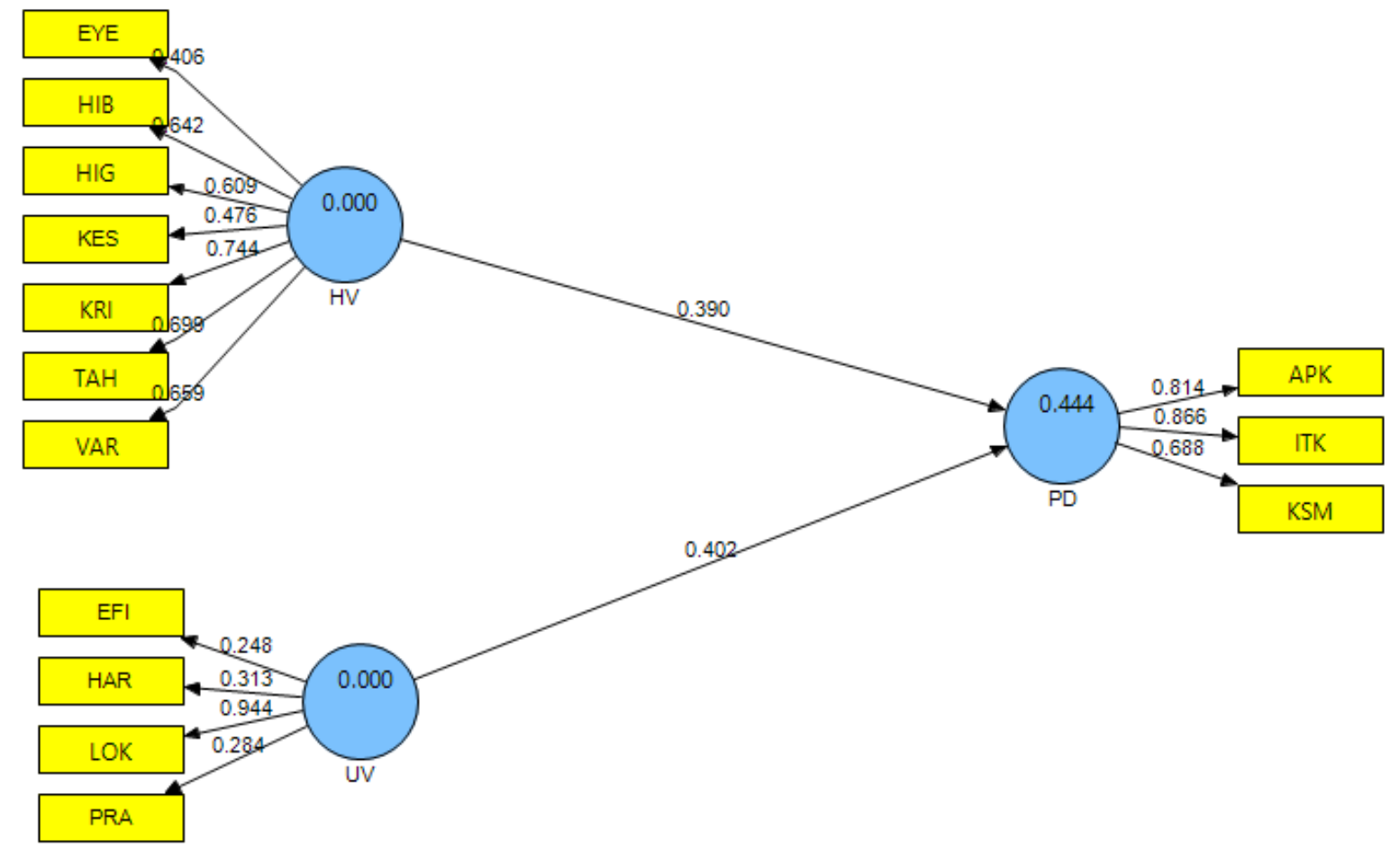

Source: PLS Output

Figure 3: Preliminary Calculate Model Results

According to Imam Ghozali [11], an indicator is considered reliable if it has a correlation value above 0.5 . Based on the results of the calculation of the initial model, there is an indicator that has a loading factor below 0.5 on the Hedonic Value and Utilitarian Value variables. Therefore, those who do not meet these criteria are excluded from the research model. 


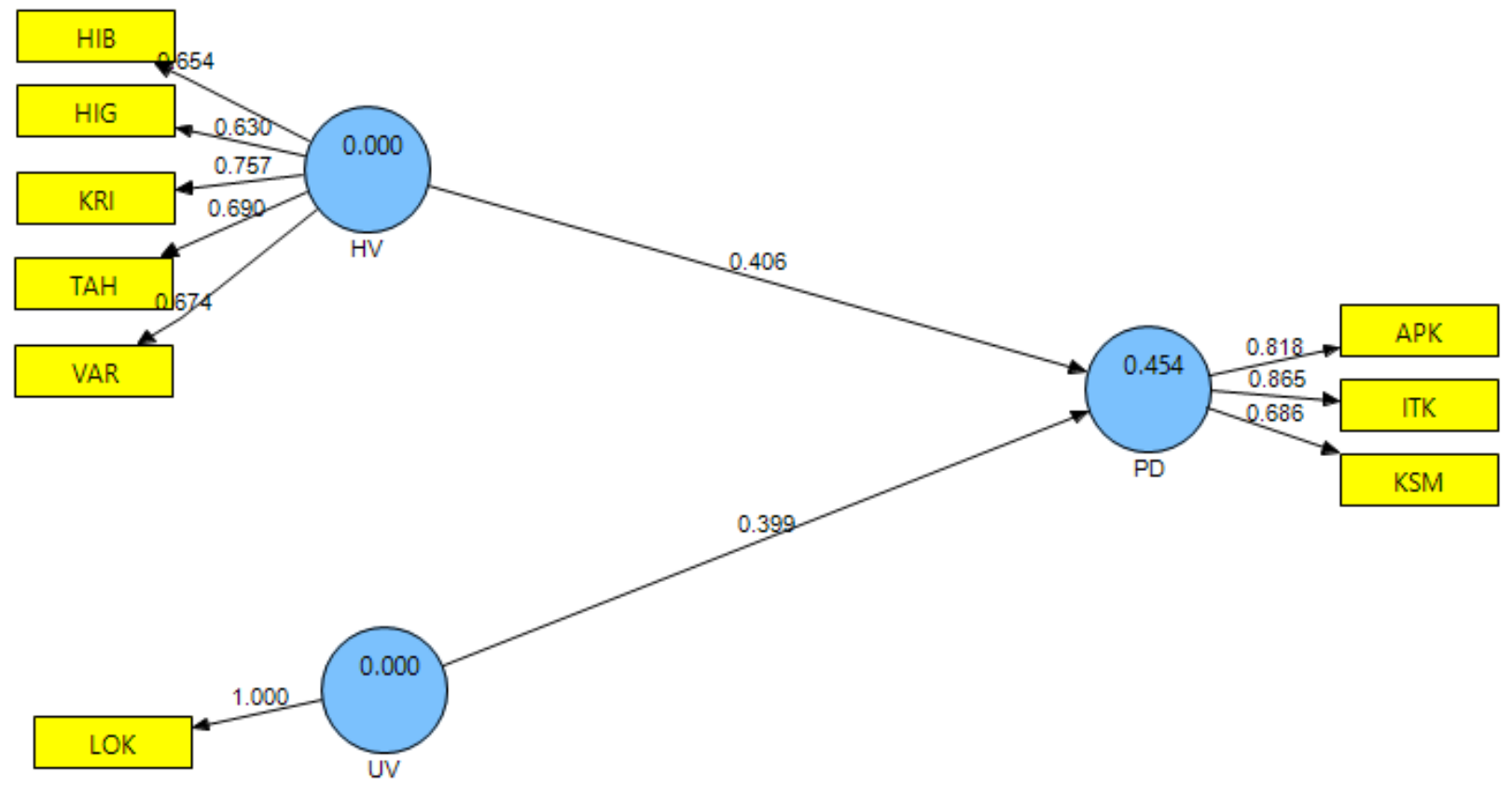

Source: PLS Output

Figure 4: Results of Calculate Model Two

Figure 4 is the final result of the research model that meets the criteria (the loading factor value is above 0.5 ).

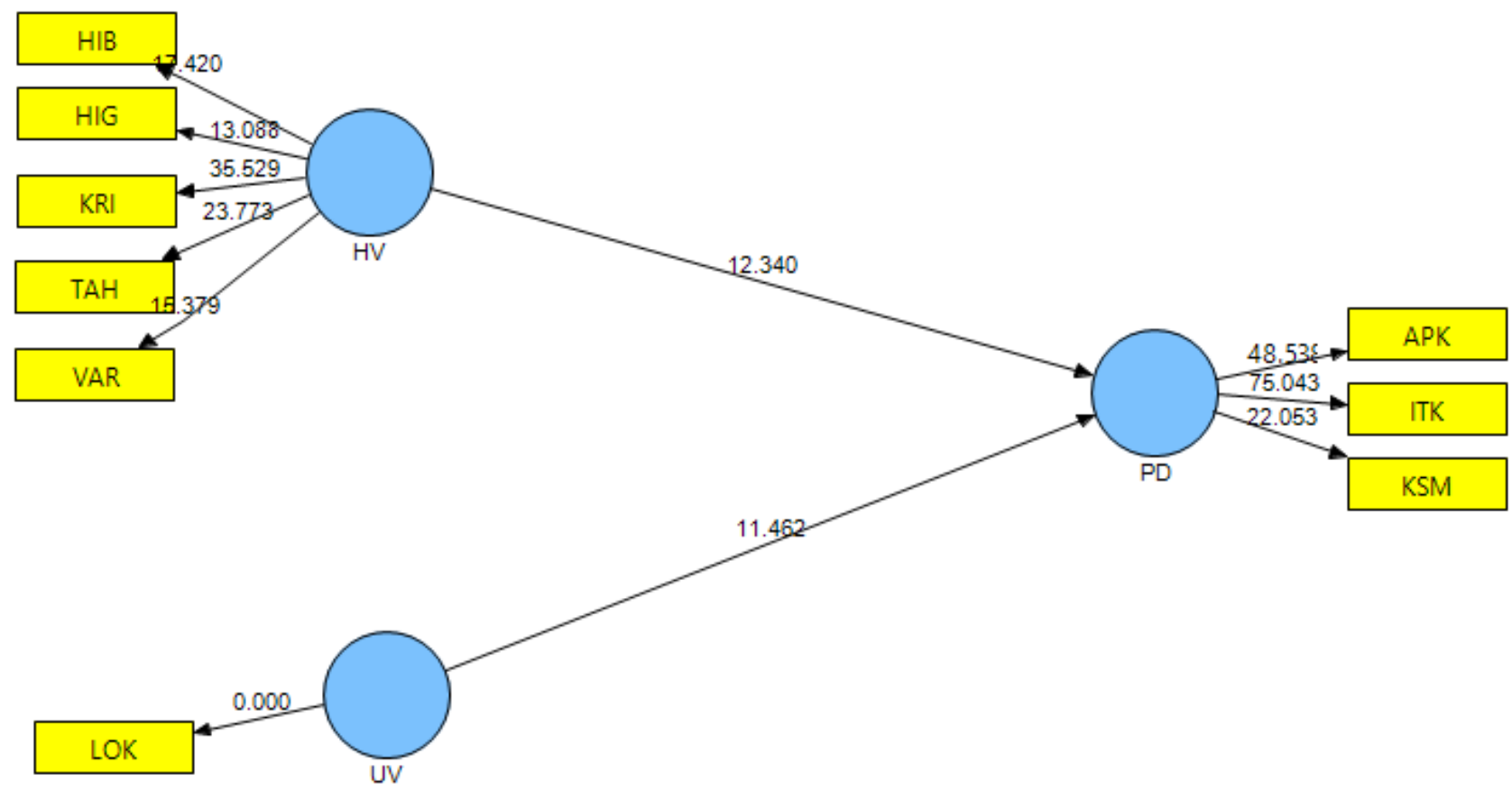

Source: PLS Output

Figure 5: Bootstrapping results of the second model 
Figure 5 is the result of the Bootstrapping of the final research model. The following is the output in the form of the total effect of the final research model.

Table 1. Results of PLS 2.3 output in the form of Total Effect

Total Effect (Means, STDEV, T-Values)

\begin{tabular}{|c|c|c|c|c|c|} 
& $\begin{array}{c}\text { Original Sample } \\
(\mathbf{O})\end{array}$ & $\begin{array}{c}\text { Sample Mean } \\
(\mathbf{M})\end{array}$ & $\begin{array}{c}\text { Standard Deviation } \\
(\mathbf{S T D E V})\end{array}$ & $\begin{array}{c}\text { Standard } \\
\text { Error } \\
(\text { STERR) }\end{array}$ & $\begin{array}{c}\text { T Statistics } \\
(\mid \mathbf{O} / \text { STERR/ }\end{array}$ \\
\hline HV -> PD & 0.405643 & 0.406250 & 0.032871 & 0.032871 & 12.340453 \\
\hline UV -> PD & 0.398584 & 0.396991 & 0.034775 & 0.34775 & 11.461740 \\
\hline
\end{tabular}

Source: PLS output

\section{DISCUSSION}

Figures 1 and 2 represent qualitative research findings in the form of themes and sub-themes. The hedonic value theme has sub-themes in the form of fun, curiosity, entertainment, variety of product flavors, hygienic factors, creativity and innovation, and attracting attention. The utilitarian value theme has sub-themes in the form of time efficiency, affordable prices, practicality, and strategic location. Whereas in the theme of purchasing decisions, there are sub-themes in the form of convenience when buying, information from friends and family and product attributes as needed. These findings complement the research conducted by Babin et al [9] and Overby and Lee [8].

Furthermore, at the quantitative stage, these findings are transformed into variables and sub-themes as indicators. Figure 5 and Table 1 are the results of this stage of research. Based on these results, it shows that the hedonic value has a significant effect on purchasing decisions in the food truck business of 0.41 and a significant value of 12.34 . Meanwhile, utilitarian value has a significant effect of 0.39 and a significant value of 11.46 on purchasing decisions in the food truck business.

The findings of this study are in line with research conducted by Chen, Chang, Chen [12] who concluded that hedonic value plays a more important role than utilitarian values in purchase intention and use of ecommerce. Chen et al [12] also stated that this is because the feelings experienced by e-commerce users generate higher curiosity not only in looking for but also in buying products. Meanwhile, Wu and Yang's research [13] which examined the decision to purchase luxury hotels in China, used 5-dimensional values, namely utilitarian value, symbolic value, hedonic value, relational value, and financial value. Wu and Yang's [13] research findings concluded that hedonic value is the most important predictor of luxury hotel purchase decisions, followed by financial value and utilitarian value. Thus, the findings of this study are supported by research by Wu and Yang [13].

\section{CONCLUSION}

The findings of this study concluded that hedonic value has a more dominant influence than the utilitarian value on purchasing decisions. It is hoped that the next researchers will be able to examine the hedonic value and utilitarian value with a broader scope, for example, the behavior of investors in buying shares in the capital market.

\section{REFERENCES}

[1] E. Annenberg, E. Kung, Information technology and product variety in the city: the case of Food Trucks. J. Urban Econ. 90, 60-78, 2015.

[2] Statista Database, Value of the US Food Truck Industry from 2014 to 2020 (in Million US Dollars). Retrieved from. (Accessed February 1, 2018), 2017.

[3] R. Batra, O.T. Ahtola, Measuring the hedonic and utilitarian sources of consumer attitudes. Market. Lett. 2 (2), 159-170, 1991.

[4] M. J. Arnold, \& K.E. Reynolds, Hedonic shopping motivations, Journal of Retailing, 79 (2), 2003, 77 95, DOI: $\quad$ https://doi.org/10.1016/S00224359(03)00007-1

[5] E.A.C. Lim, S.H. Ang, Hedonic vs. Utilitarian consumption: a cross-cultural perspective based on cultural conditioning. J. Bus. Res. 61 (3), 2008, 225 232.

[6] E. Bridges, R. Florsheim, Hedonic and utilitarian shopping goals: the online experience. J. Bus. Res. 61 (4), 2008, 309-314.

[7] K. Ryu, H. Han, S. Jang, Relationships among hedonic and utilitarian values, satisfaction, and behavioral intentions in the fast-casual restaurant industry. Int. J. Contemporary Hospital. Manag. 22 (3), 2010, 416-432.

[8] Overby, Jeffrey \& Eun-Ju Lee, The Effects of Utilitarian and Hedonic Online Shopping Value on Consumer Preference and Intentions, Journal of 
Business Research. 59.1160-1166. 10.1016 / j.jbusres.2006.03.008, 2006.

[9] B.J. Babin, W.R. Darden, M. Griffin, Work and/or fun: measuring hedonic and utilitarian shopping value. J. Consumer Res. 20 (4), 644-656, 1994.

[10] S.B. Kim, K.A. Sun, D.Y. Kim, the influence of consumer value-based factors on attitude-behavioral intention in social commerce: the differences between high-and low-technology experience groups, J. Travel Tourism Market. 30 (1-2), 108$125,2013$.

[11] I. Ghozali, Structural equation modeling alternative mode with partial least square, Edition 2. BP-Undip, 2008.

[12] Chen, Kuo wen, Dong-Shang Chang, Chun-Cheng Chen, The Role of Utilitarian and Hedonic Values on Users' Continued Usage and Purchase Intention in a Social Commerce Environment. Journal of Economics and Management, Vol. 13, No. 2, 193220, 2017.

[13] Wu, Ben. Wan, Yang. What do Chinese consumers want? A value framework for luxury hotels in China, International Journal of Contemporary Hospitality Management, 2018. 